\title{
Maternal protein reserves and their influence on lactational performance in rats 4 . Tissue protein synthesis and turnover associated with mobilization of maternal protein
}

\author{
BY A. P. PINE, N. S. JESSOP* AND G. F. ALLAN \\ Institute of Ecology and Resource Management, University of Edinburgh, West Mains Road, \\ Edinburgh EH9 $3 J G$ \\ AND J. D. OLDHAM \\ Genetics and Behavioural Sciences Department, Scottish Agricultural College, West Mains Road, \\ Edinburgh EH9 $3 J G$
}

(Received 3 March 1993 - Revised 9 March 1994 - Accepted 12 April 1994)

\begin{abstract}
The present study was undertaken to investigate the changes in muscle protein turnover involved in the rapid mobilization of protein in rats subjected to severe protein restriction during lactation. Estimates of mammary gland and liver protein synthesis were also made during lactation. Multiparous female Sprague-Dawley rats, caged individually following mating, were offered a high-protein diet $(\mathrm{H} ; 215 \mathrm{~g}$ crude protein $(\mathrm{N} \times 6.25 ; \mathrm{CP}) / \mathrm{kg}$ dry matter $(\mathrm{DM})$ ) ad lib. until parturition. Following parturition, half the females continued to receive diet $\mathrm{H}$, whilst the remainder were offered a diet low in protein $(\mathrm{L} ; 90 \mathrm{~g}$ CP/kg DM) ad lib. On days 2, 4, 8 and 12 of lactation, groups of females were used in the estimation of tissue protein synthesis (flooding dose of $\left[^{3} \mathrm{H}\right]$ phenylalanine) immediately after a milk sample had been obtained. Rates of muscle protein synthesis were unchanged during lactation in group $\mathbf{H}$. The feeding of diet $L$ during lactation reduced the muscle protein synthesis on day 12 to rates that were lower than group $H$ and also the rate on diet $L$ on day $2(P<0.01)$. However, this fall in muscle protein synthesis was not rapid and muscle fractional synthesis rate (FSR) was different from group $\mathrm{H}$ only from day $8(P<0.05)$. Estimated rates of mammary protein synthesis appeared to be generally unchanged by dietary treatment or stage of lactation. Liver FSR was also unchanged by dietary protein supply or stage of lactation. The effect of dietary protein restriction on liver size and protein content during lactation influenced liver absolute synthesis rate (ASR), and on days 8 and 12 of lactation liver ASR was lower in group $L$ than in group $H(P<0.001)$. The loss of muscle protein in rats fed on diet $L$ during lactation $(133 \mathrm{mg})$ occurred mainly between days 2 and 8 of lactation and was primarily associated with a dramatic increase in degradation (13.0\% per d), with the decline in synthesis having a much smaller role. A decline in muscle protein degradation during the latter half of lactation was part of the mechanism that prevented excessive muscle protein catabolism. It is thought that the estimation of mammary protein synthesis in the present study was impaired by the milk sampling procedure previously used.
\end{abstract}

Lactation: Protein synthesis: Protein degradation: Rat

It is now well recognized that lactating females can supplement their available nutrient supply by mobilizing endogenous reserves of protein. The use of such reserves by dairy ruminants is most frequently associated with early lactation, when the gap between feed intake and milk yield creates an imbalance between nutrient supply and demand (Belyea $e t$ al. 1978), while in rodents such maternal protein loss is promoted by periods of protein

* For reprints. 
undernutrition (Naismith et al. 1982; Pine et al. 1994b) during both gestation and lactation. Since skeletal muscles are the primary site of protein mobilization (Swick \& Benevenga, 1977), several studies, involving both ruminants and non-ruminants, have investigated the possible adaptive mechanisms of muscle protein turnover involved during lactation.

In lactating ruminants, the net loss of hindlimb muscle protein has been reported to be associated with a fall in protein synthesis in goats (Champredon et al. 1990; Baracos et al. 1991) and with an increase in degradation in sheep (Vincent \& Lindsay, 1985). Other workers using lactating sheep have concluded that the mechanism involved depended on the individual muscle concerned (Bryant \& Smith, 1982). Similar studies involving lactating rodents could not attribute the protein loss from protein-restricted females to either alterations in carcass protein turnover (Sainz et al. 1986) or muscle protein synthesis (Sampson \& Jansen, 1984a), although from measurements of urinary 3-methylhistidine excretion, Sainz et al. (1984) suggested that an increase in protein degradation was involved. As a result of these studies, the possible controlling mechanisms responsible for muscle loss remain uncertain and confused.

From an earlier study in this laboratory (Pine et al. 1994a) it was suggested that the loss of muscle protein from female rats subjected to severe protein restriction during the first $12 \mathrm{~d}$ of lactation was associated with both a fall in synthesis and an increase in degradation, with the increase in degradation being quantitatively more important. In that study, muscle protein synthesis was estimated at the start and end of the $12 \mathrm{~d}$ period of lactation, while the rate of protein degradation was calculated assuming a constant rate of muscle protein loss. However, from recorded changes in lactational performance (litter-weight gain; Pine et al. 1994a, b) and the suggestion that in similarly treated females the loss of muscle protein occurs rapidly during early lactation $(1.0 \mathrm{~g} / \mathrm{d})$ before reaching an apparent metabolic limit (days 6-9) after which such protein loss is severely impaired (Pine et al. 1994a), this assumed constant rate of maternal protein loss is clearly an over-simplification of true events. It is therefore apparent that the measurement of muscle protein metabolism at two stages during lactation cannot accurately describe the changes in muscle protein turnover involved in such a pattern of mobilization. Changes in muscle protein metabolism throughout lactation require description and will be reported in the present study.

In both ruminants and non-ruminants, whole-body protein turnover is considerably increased during lactation through an elevation of mammary gland, liver and gastrointestinal tract protein synthesis (Millican et al. 1987; Champredon et al. 1990). This increase is partly the result of organ hypertrophy/hyperplasia which is in turn promoted by an enhanced feed intake (Williamson, 1980; Vernon, 1988). In rodents, liver fractional synthesis rate (FSR; \% per d) during lactation is relatively unaffected by dietary protein quantity or quality, although such liver hypertrophy, and thus an increase in absolute synthesis rate (ASR; $\mathrm{mg} / \mathrm{d}$ ), is prevented by dietary protein restriction (Sampson \& Jansen, 1984a; Pine et al. 1994a). Mammary protein synthesis (FSR and ASR) is more sensitive, and is significantly impaired by dietary protein restriction during lactation (Sampson \& Jansen 1984a; Sampson et al. 1986), although prior restriction during gestation has been shown not to prevent protein synthesis from increasing during lactation when adequate nutrition is provided (Pine et al. 1994a).

Mammary protein synthesis, despite being crucial to both the secretion of milk protein and the maintenance of mammary integrity, has been shown to be correlated with milk secretion (Sampson \& Jansen, 1985) and also increases from early to peak lactation (Jansen \& Hunsaker, 1986; Millican et al. 1987). However, the pattern of this increase and possible changes imposed by dietary protein restriction remain to be elucidated. Whether the suggested fall in milk secretion that results from the depletion of maternal protein reserves is also reflected in alterations in mammary protein synthesis is unknown. 
The objectives of the current study were to investigate the changes in protein turnover in muscle, mammary gland and liver during the rapid mobilization of protein from female rats subjected to severe protein undernutrition during early lactation.

\section{MATERIALS AND METHODS}

The females used in this study were also involved in the investigation of changes in milk composition during lactation, the results for which have been reported previously (Pine $e t$ al. $1994 c$ ). A similar experimental protocol was therefore followed in both studies, with milk composition and rates of protein synthesis being estimated in the same female offered a diet of either a high $(\mathrm{H} ; 215 \mathrm{~g}$ crude protein $(\mathrm{N} \times 6.25 ; \mathrm{CP}) / \mathrm{kg}$ dry matter (DM)) or low (L; $90 \mathrm{~g} \mathrm{CP} / \mathrm{kg} \mathrm{DM}$ ) protein: energy ratio during lactation.

\section{Experimental protocol}

For a full description of the rat strain, female numbers, diet composition, feeding procedure, data collection and litter size used in the present study the reader is referred to Pine et al. $(1994 c)$. Groups of females $(n 4)$ were used on days 2, 4, 8 and 12 of lactation for the estimation of tissue protein synthesis immediately after a milk sample had been obtained. Briefly, the experimental design involved thirty-two multiparous female rats being offered the high-protein diet $\mathrm{H}$ ad lib. from conception until parturition, after which half continued to receive diet $\mathrm{H}$ ad lib. during lactation, whilst the remainder were offered the low-protein diet L. During lactation, dams on both dietary treatments were then used in the analysis of milk composition and tissue protein metabolism. Throughout the experiment, maternal body-weight and feed intake were recorded daily, whilst litter weights were recorded during the $12-\mathrm{d}$ lactation period.

The milking procedure involved an initial $2 \mathrm{~h}$ separation of dam and litter at the start of the light period, after which the dams were lightly anaesthetized (diethyl ether) and injected subcutaneously with 5 IU oxytocin. Milk samples were then obtained from the left thoracic and abdominal teats. While the dam was still anaesthetized, in vivo rates of tissue protein synthesis were estimated.

\section{Measurement of tissue protein synthesis}

Rates of in vivo total protein synthesis were measured during lactation in the gastrocnemius muscle, mammary gland and liver using the flooding-dose technique of Garlick et al. (1980). Technical aspects of this procedure have been previously described elsewhere (Pine et al. 1994a).

Fractional synthesis rates (FSR) are calculated using the equation:

$$
\operatorname{FSR}(\% \text { per } \mathrm{d})=\frac{S_{B} \times 100}{S_{A} \times t},
$$

where $S_{B}$ and $S_{A}$ are the specific activity of protein-bound and free phenylalanine respectively, and $t$ is the time elapsed between injection and tissue cooling. Absolute synthesis rates (ASR; mg/d) are calculated using the FSR, organ weight and tissue protein content.

In the present study, samples of the right hand abdominal mammary gland were used in the estimation of protein synthesis since the left hand gland had received physical manipulation during the milking procedure. Once the tissue samples had been cooled in liquid $\mathrm{N}_{2}$, the remaining liver and right hand mammary gland were dissected and weighed. 
Tissue protein content was measured using the method of Lowry et al. (1951) with bovine serum albumin as a standard, and the RNA concentration was estimated as described by Munro \& Fleck (1969), with muscle RNA calculated using the equation of Ashford \& Pain (1986). RNA activity is defined as mg protein synthesized/mg RNA and is often used as an indication of the protein synthetic capacity of a tissue (Lobley, 1993). Diethyl ether was chosen as the anaesthetic because it has been previously reported not to affect rates of tissue protein synthesis during lactation (Sampson et al. 1984).

\section{Statistical analysis}

Dietary effects on rates of protein synthesis and tissue composition were analysed by twoway analysis of variance, and by calculation of least significant differences; $t$ tests were used to compare sample means between diets and individual days. Changes in muscle protein content during lactation were also analysed by analysis of variance, with day 1 lactation body-weight as a covariate (Genstat5).

\section{RESULTS}

The effects of the lactational dietary treatments on feed intake, maternal body-weight loss, and lactational performance (litter-weight gain) have been previously reported (Pine et al. 1994c) and are shown in Figs 1, 2 and 3.

The feeding of diet $\mathrm{L}$ during lactation did not allow the increase in feed intake seen on diet $\mathbf{H}$ (Fig. 1) and, as a consequence of this constraint on intake, resulted in a considerable loss of weight (Fig. 2) and reduced litter-weight gain (Fig. 3).

\section{The effects of the lactation dietary treatments on muscle weight, composition and rates of in vivo protein synthesis}

The weight, composition and estimated rates of protein synthesis in the gastrocnemius muscle from female rats offered diets $\mathrm{H}$ and $\mathrm{L}$ during lactation are shown in Table 1 .

The feeding of diet $\mathrm{H}$ during lactation promoted no significant change in muscle weight, protein content, RNA content or FSR and ASR in relation to stage of lactation. However, dietary protein restriction during lactation did result in significant alterations in muscle protein metabolism.

The feeding of diet $\mathrm{L}$ had reduced, by day 12 of lactation, the muscle weight, protein and RNA contents of group L compared with both that of group $\mathrm{H}(P<0.01)$ on day 12 and the respective values for group $\mathrm{L}$ on day $2(P<0.05)$. The difference in muscle weight between dietary groups was apparent by day $4(P<0.05)$, while muscle protein and RNA contents were significantly different by day 8 . Group $\mathrm{L}$ muscle protein loss between days 2 and 12 of lactation was approximately $133 \mathrm{mg}$, although the majority of this loss $(120 \mathrm{mg})$ had occurred by day 8 . The calculated changes, from covariate analysis, in the muscle protein content of groups $\mathrm{H}$ and $\mathrm{L}$ during lactation confirmed the significant $(P<0.01)$ reduction in muscle protein with dietary protein restriction and are shown in Fig. 4.

Rates of muscle protein synthesis were significantly reduced during lactation by the feeding of diet L, with the FSR and ASR of group L on day 12 being lower than both that of group $\mathbf{H}(P<0.01)$ and of group L on day $2(P<0.01)$. However, this dietary protein restriction did not promote a rapid fall in protein synthesis and the reduction in FSR only became significant during the last $4 \mathrm{~d}$ (Table 1). This reduction in muscle protein synthesis was reflected in a decline in the RNA activity of group L, which on day 12 of lactation was lower than both that of group $\mathrm{H}(P<0.05)$ and of the muscle RNA activity of group $\mathrm{L}$ on day $2(P<0.01 ;$ Table 1$)$. 


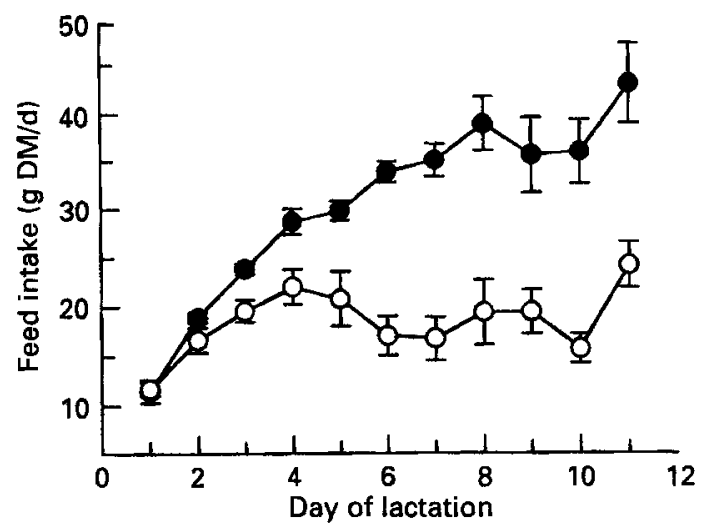

Fig. 1. Daily feed intake (g dry matter (DM)) of female rats offered either a high (O)- or a low (O)-protein diet during lactation. Values are means for all rats offered each diet at each stage of lactation, with their standard errors indicated by vertical bars. For details of diets, see Pine et al. (1994c).

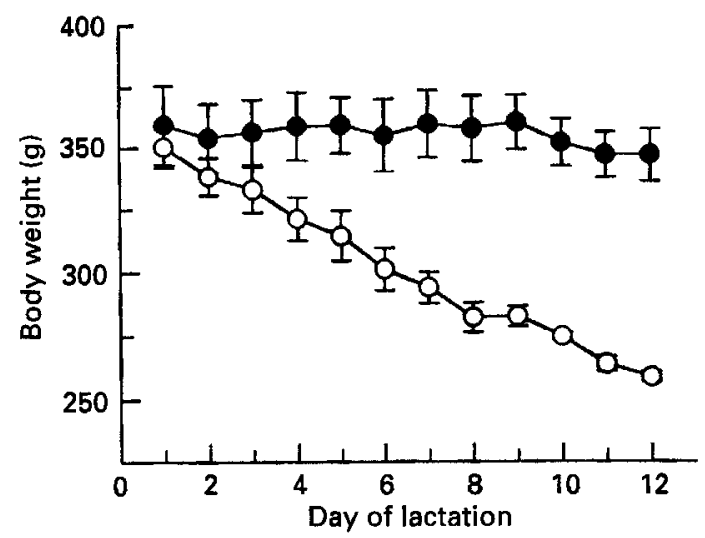

Fig. 2. Change in body weight between days 1 and 12 of lactation for female rats offered either a high $(\mathbf{O}, n 4)$ or a low $(O, n 4)$-protein diet during lactation. Females were weighed at the same time each day. Values are means with their standard errors represented by vertical bars. For details of diets, see Pine et al. (1994c).

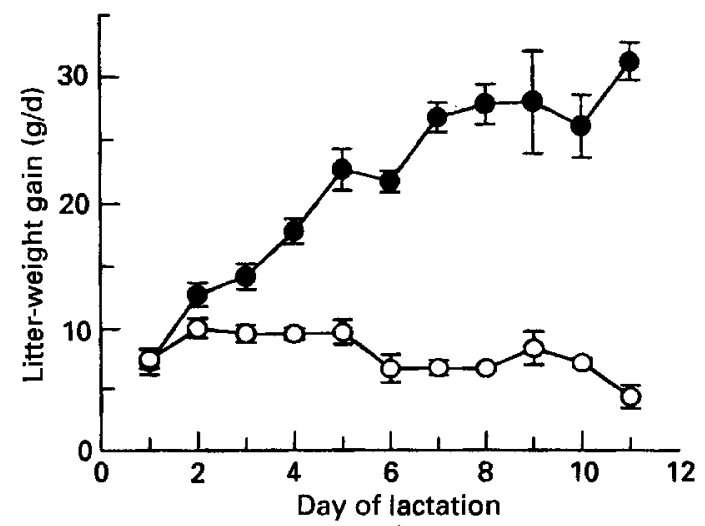

Fig. 3. Daily litter-weight gain (g) for female rats offered either a high (๑)- or a low (O)-protein diet during lactation. Values are means for all rats offered each diet at each stage of lactation, with their standard errors represented by vertical bars. For details of diets, see Pine et al. $(1994$ c). 


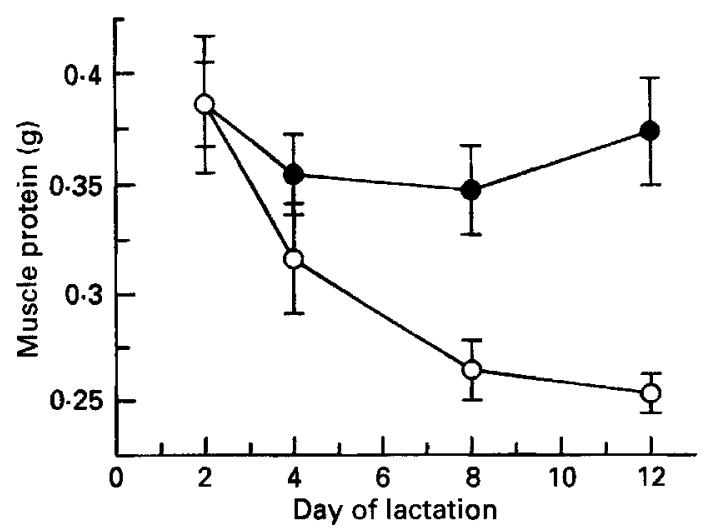

Fig. 4. Changes in the protein content (g) of skeletal muscle (gastrocnemius), adjusted for day 1 of lactation body weight, of female rats offered either a high (O)- or a low (O)-protein diet during lactation. Muscles were dissected from rats $(n)$ that were slaughtered on day $2,4,8$ or 12 of lactation. Values are means with their standard errors represented by vertical bars. For details of diets, see Pine et al. (1994c).

Table 1. Weight, composition and in vivo rates of protein synthesis of gastrocnemius muscle of rats given either a high $(H)$ - or a low $(L)$-protein diet during lactation $\dagger$

(Mean values with their standard errors for four rats)

\begin{tabular}{|c|c|c|c|c|c|}
\hline & & \multicolumn{4}{|c|}{ Lactation diet } \\
\hline & & \multicolumn{2}{|c|}{$\mathbf{H}$} & \multicolumn{2}{|c|}{$\mathbf{L}$} \\
\hline & & Mean & $\mathbf{S E}$ & Mean & $\mathbf{S E}$ \\
\hline \multirow[t]{4}{*}{ Weight (g): } & Day 2 & $1 \cdot 46^{\mathrm{a}}$ & $0 \cdot 10$ & $1 \cdot 48^{a}$ & $0 \cdot 10$ \\
\hline & 4 & $1 \cdot 50^{\mathrm{a}}$ & 0.05 & $1 \cdot 27^{\mathrm{b} *}$ & 0.08 \\
\hline & 8 & $1 \cdot 42^{\mathrm{a}}$ & 0.03 & $1 \cdot 17^{\mathrm{b} *}$ & 0.02 \\
\hline & 12 & $1.42^{\mathrm{a}}$ & 0.03 & $1 \cdot 13^{\mathrm{b} * *}$ & 0.03 \\
\hline \multirow[t]{4}{*}{ Protein (mg): } & Day 2 & $387 \cdot 2^{a}$ & $34 \cdot 9$ & $385 \cdot 4^{2}$ & $22 \cdot 1$ \\
\hline & 4 & $353 \cdot 9^{\mathrm{a}}$ & $15 \cdot 6$ & $317 \cdot 1^{\mathrm{a}}$ & $24 \cdot 5$ \\
\hline & 8 & $345 \cdot 8^{a}$ & $25 \cdot 4$ & $265 \cdot 3^{\mathrm{b} *}$ & $12 \cdot 9$ \\
\hline & 12 & $373 \cdot 7^{a}$ & $29 \cdot 9$ & $252 \cdot 1^{\mathrm{b} * *}$ & $9 \cdot 5$ \\
\hline \multirow[t]{4}{*}{ RNA (mg): } & Day 2 & $1 \cdot 7^{\mathrm{a}}$ & $0 \cdot 1$ & $1 \cdot 6^{\mathrm{a}}$ & 0.2 \\
\hline & 4 & $1 \cdot 7^{\mathrm{a}}$ & $0 \cdot 2$ & $1 \cdot 5^{\mathrm{ab}}$ & $0 \cdot 2$ \\
\hline & 8 & $1 \cdot 9^{\mathrm{a}}$ & 00 & $1 \cdot 5^{\mathrm{ab}) *}$ & 0.1 \\
\hline & 12 & $1 \cdot 8^{\mathrm{a}}$ & $0 \cdot 1$ & $1 \cdot 2^{\mathrm{b} * *}$ & 0.0 \\
\hline \multirow[t]{4}{*}{ FSR (\% per d): } & Day 2 & $2 \cdot 9^{a}$ & 0.3 & $3 \cdot 3^{3}$ & 0.4 \\
\hline & 4 & $3 \cdot 5^{\mathrm{a}}$ & 0.2 & $2 \cdot 8^{\mathfrak{a}}$ & 0.4 \\
\hline & 8 & $3 \cdot 6^{\mathrm{a}}$ & $0 \cdot 3$ & $2 \cdot 7^{\mathrm{ab} *}$ & $0 \cdot 1$ \\
\hline & 12 & $3 \cdot 5^{a}$ & 0.2 & $2 \cdot 0^{\mathrm{b} * *}$ & $0 \cdot 2$ \\
\hline \multirow[t]{4}{*}{$\operatorname{ASR}(\mathrm{mg} / \mathrm{d}):$} & Day 2 & $11 \cdot 3^{\mathrm{a}}$ & $2 \cdot 1$ & $12 \cdot 8^{\mathrm{n}}$ & $2 \cdot 0$ \\
\hline & 4 & $12 \cdot 6^{\mathrm{a}}$ & $1 \cdot 3$ & $8 \cdot 9^{\mathrm{ab}}$ & $1 \cdot 2$ \\
\hline & 8 & $12 \cdot 2^{a}$ & 0.7 & $7 \cdot 3^{b *}$ & 0.4 \\
\hline & 12 & $12 \cdot 3^{a}$ & 1.9 & $5 \cdot 0^{\mathrm{b} * *}$ & $0 \cdot 2$ \\
\hline \multirow[t]{4}{*}{ RNA activity $\$:$} & Day 2 & $6 \cdot 6^{a}$ & $1 \cdot 0$ & $7 \cdot 6^{\mathrm{a}}$ & 0.9 \\
\hline & 4 & $7 \cdot 6^{a}$ & 0.8 & $6 \cdot 4^{\mathrm{ab}}$ & $1 \cdot 3$ \\
\hline & 8 & $6 \cdot 5^{\mathrm{a}}$ & $0 \cdot 3$ & $5 \cdot 1^{\mathrm{b}}$ & 0.4 \\
\hline & 12 & $6 \cdot 8^{a}$ & $1 \cdot 0$ & $4 \cdot 2^{b *}$ & $0 \cdot 3$ \\
\hline
\end{tabular}

FSR, fractional synthesis rate; ASR, absolute synthesis rate.

a, b Mean values in the same column and block bearing different superscript letters were significantly different $(P<0 \cdot 05)$.

Mean values were significantly different from those for group $\mathrm{H}:{ }^{*} P<0.05,{ }^{* *} P<0 \cdot 01,{ }^{* * *} P<0 \cdot 001$.

$\dagger$ For details of procedures, see pp. 833 834. For details of diets, see Pine et al. (1994c).

$\ddagger \mathrm{mg}$ protein synthesized/mg RNA. 
Table 2. Mammary gland weight $\dagger$, composition and rates of protein synthesis of rats given either a high $(H)$ - or a low $(L)$-protein diet during lactation $\ddagger$

(Mean values with their standard errors for four rats)

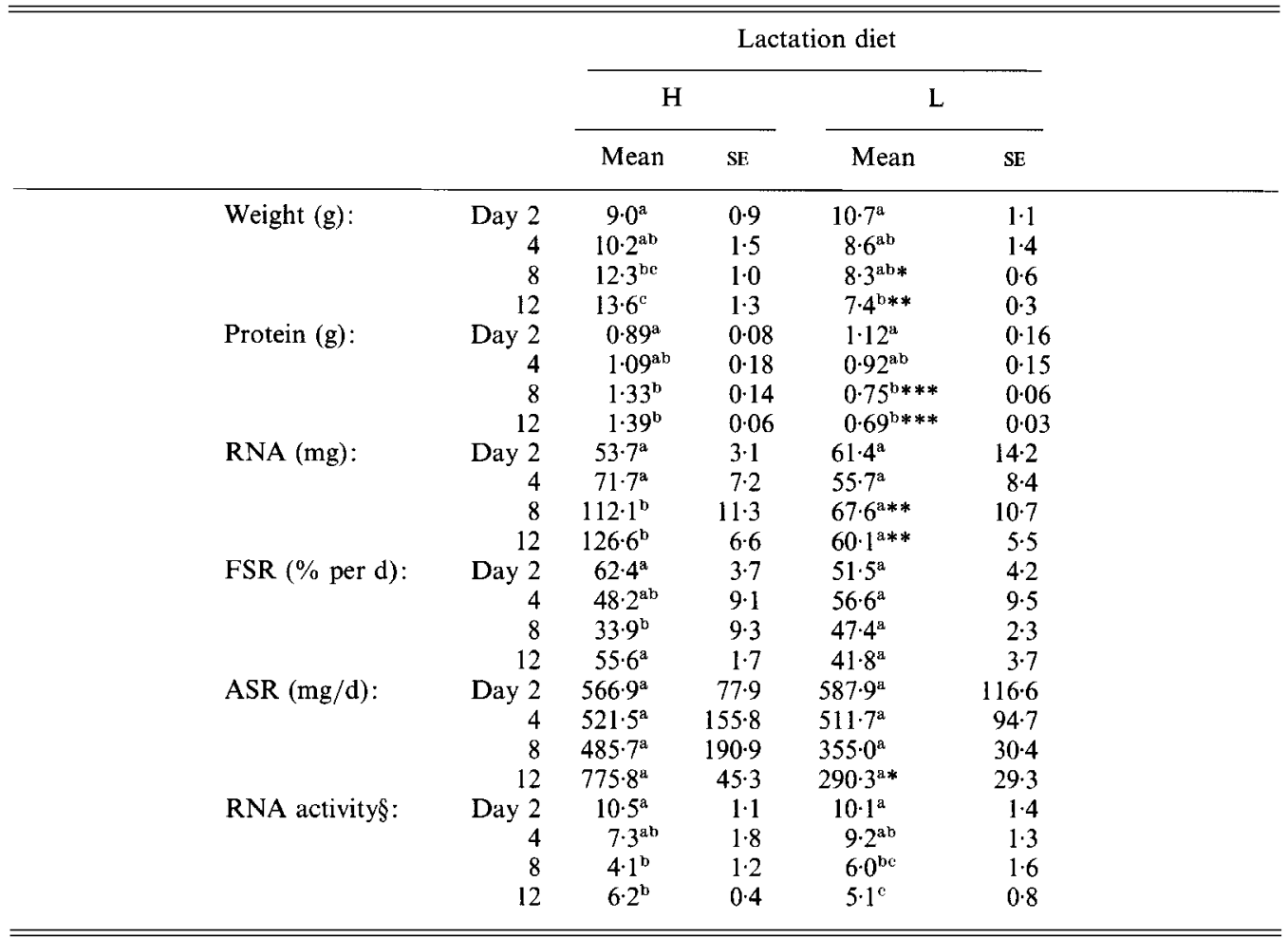

FSR, fractional synthesis rate; ASR, absolute synthesis rate.

a.b.c Mean values within a column and block bearing different superscripts were significantly different $(P<$ $0 \cdot 05)$.

Mean values were significantly different from those of group $\mathrm{H}:{ }^{*} P<0.05,{ }^{* *} P<0.01$, *** $P<0.001$.

$\dagger$ Right hand abdominal and thoracic mammary gland.

\$ For details of procedures, see pp. 833-834. For details of diets, see Pine et al. $(1994 \mathrm{c})$.

$\S \mathrm{mg}$ protein synthesized/mg RNA.

The effect of the lactation dietary treatments on mammary gland weight, composition and in vivo rates of protein synthesis

The weight of the right hand mammary gland, its composition and estimates rates of protein synthesis from female rats offered diets $\mathrm{H}$ and $\mathrm{L}$ during lactation are shown in Table 2.

The feeding of diet $\mathrm{H}$ during lactation promoted a significant increase in mammary gland weight, protein and RNA contents, whilst diet $\mathrm{L}$ resulted in significant loss of mammary weight and protein content although not of RNA. As a consequence, on days 8 and 12 of lactation, mammary gland weight $(P<0.05)$, protein content $(P<0.01)$ and RNA content $(P<0.01)$ were greater in dams offered diet $\mathrm{H}$. For both dietary groups the mammary gland weight and protein content on day 12 were significantly different from their respective values during early lactation.

However, in both dietary groups, rates of mammary protein synthesis were generally unaltered throughout lactation and, apart from day 12 ASR, were unaffected by the dietary 
Table 3. Liver weight, composition and rates of protein synthesis of rats given either a high $(H)$ - or a low $(L)$-protein diet during lactation $\dagger$

(Mean values with their standard errors for four rats)

\begin{tabular}{|c|c|c|c|c|c|}
\hline & & \multicolumn{4}{|c|}{ Lactation diet } \\
\hline & & \multicolumn{2}{|c|}{$\mathrm{H}$} & \multicolumn{2}{|c|}{$\mathrm{L}$} \\
\hline & & Mean & SE & Mean & SE \\
\hline \multirow[t]{4}{*}{ Weight (g): } & Day 2 & $11 \cdot 7^{a}$ & 0.8 & $12 \cdot 2^{\mathrm{a}}$ & 0.4 \\
\hline & 4 & $12 \cdot 1^{a}$ & $1 \cdot 0$ & $11 \cdot 2^{\mathrm{ah}}$ & 0.5 \\
\hline & 8 & $14 \cdot 5^{b}$ & 0.6 & $10 \cdot 0^{\mathrm{b} * * *}$ & 0.2 \\
\hline & 12 & $17 \cdot 2^{\mathrm{b}}$ & 0.7 & $10 \cdot 0^{\mathrm{b} * * *}$ & 0.6 \\
\hline \multirow[t]{4}{*}{ Protein (g): } & Day 2 & $2 \cdot 28^{\mathrm{a}}$ & 0.17 & $2 \cdot 11^{\mathrm{a}}$ & 0.20 \\
\hline & 4 & $2 \cdot 23^{\mathrm{a}}$ & 0.24 & $1 \cdot 85^{\mathrm{ab}}$ & 0.06 \\
\hline & 8 & $2 \cdot 82^{b}$ & 0.06 & $1 \cdot 83^{\text {ab** }}$ & 0.07 \\
\hline & 12 & $3 \cdot 21^{\mathrm{D}}$ & 0.19 & $1.63^{\mathrm{b} * * * *}$ & 0.05 \\
\hline \multirow[t]{4}{*}{ RNA (mg): } & Day 2 & $127 \cdot 2^{\mathrm{a}}$ & $10 \cdot 4$ & $125 \cdot 2^{\mathrm{a}}$ & $2 \cdot 6$ \\
\hline & 4 & $121 \cdot 4^{\mathrm{a}}$ & $3 \cdot 4$ & $113 \cdot 2^{a b}$ & $4 \cdot 7$ \\
\hline & 8 & $135 \cdot 3^{\mathrm{a}}$ & 3.4 & $102 \cdot 0^{\mathrm{bc} * *}$ & $1 \cdot 7$ \\
\hline & 12 & $155 \cdot 6^{\mathrm{b}}$ & 6.5 & $98 \cdot 2^{\mathrm{c} * *}$ & $2 \cdot 8$ \\
\hline \multirow[t]{4}{*}{ FSR $(\%$ per $d):$} & Day 2 & $105 \cdot 6^{\mathrm{a}}$ & $7 \cdot 6$ & $84 \cdot 5^{3 *}$ & $6 \cdot 8$ \\
\hline & 4 & $79 \cdot 0^{\mathrm{b}}$ & $5 \cdot 5$ & $82 \cdot 0^{\mathrm{a}}$ & $8 \cdot 4$ \\
\hline & 8 & $849^{b}$ & $3 \cdot 4$ & $82 \cdot 6^{a}$ & 6.6 \\
\hline & 12 & $79 \cdot 6^{b}$ & $4 \cdot 1$ & $81 \cdot 4^{a}$ & $8 \cdot 3$ \\
\hline \multirow[t]{4}{*}{$\operatorname{ASR}(g / d)$} & Day 2 & $2 \cdot 4^{\mathrm{a}}$ & $0 \cdot 2$ & $1 \cdot 8^{a *}$ & $0 \cdot 2$ \\
\hline & 4 & $1 \cdot 8^{b}$ & $0 \cdot 2$ & $1.5^{\mathrm{a}}$ & $0 \cdot 1$ \\
\hline & 8 & $2 \cdot 4^{a}$ & $0 \cdot 1$ & $1 \cdot 5^{* * * *}$ & 0.1 \\
\hline & 12 & $2 \cdot 5^{a}$ & $0 \cdot 1$ & $1 \cdot 3^{a * * *}$ & 0.2 \\
\hline \multirow[t]{4}{*}{ RNA activity ${ }_{+}:$} & Day 2 & $19 \cdot 1^{2}$ & 1.9 & $14 \cdot 2^{a *}$ & 1.7 \\
\hline & 4 & $14 \cdot 4^{b}$ & $1 \cdot 3$ & $14 \cdot 9^{\mathrm{a}}$ & 1.5 \\
\hline & 8 & $17 \cdot 8^{\mathrm{ab}}$ & $1 \cdot 3$ & $14.9^{\mathrm{a}}$ & 1.5 \\
\hline & 12 & $16 \cdot 4^{a b}$ & 0.9 & $13 \cdot 6^{\mathrm{a}}$ & 1.6 \\
\hline
\end{tabular}

FSR, fractional synthesis rate; ASR, absolute synthesis rate.

a.b.c Mean values within a column and block bearing different superscript letters were significantly different $(P<0.05)$.

Mean values were significantly different from those of group $\mathrm{H}:{ }^{*} P<0.05,{ }^{* *} P<0.01,{ }^{* * *} P<0.001$.

$\dagger$ For details of procedures, see pp. 833-834. For details of diets, see Pine et al. $(1994 c)$.

$\$ \mathrm{mg}$ protein synthesized/mg RNA.

protein:energy ratio. Although rates of protein synthesis were unchanged, estimated mammary RNA activity was significantly reduced during lactation in both dietary groups, and by day 12 had declined $(P<0.05)$ to 6.15 and $5.05 \mathrm{mg}$ protein $/ \mathrm{mg}$ RNA in groups $H$ and $L$ respectively. For groups $H$ and $L$, RNA activities were not different throughout lactation.

The effect of the lactation dietary treatments on liver weight, composition and in vivo rates of protein synthesis

The liver weight, composition and rates of protein synthesis from female rats offered diets $\mathrm{H}$ and $\mathrm{L}$ during lactation are shown in Table 3.

The feeding of diets $\mathrm{H}$ and $\mathrm{L}$ during lactation had similar qualitative effects on liver size and composition as those previously described for the mammary gland. During lactation the feeding of diet $\mathrm{H}$ promoted considerable liver anabolism so that by day 12 , liver weight $(P<0.01)$, liver protein $(P<0.001)$ and RNA contents $(P<0.01)$ had all increased 
compared with those on day 2 . On the other hand, the feeding of diet $\mathrm{L}$ resulted in a reduction in liver size during lactation, so that by day 8 liver weight $(P<0.001)$, liver protein and RNA contents $(P<0.01)$ of group $\mathrm{L}$ were all lower than those of group $\mathrm{H}$.

Liver FSR (\% per d), apart from that on day 2 in group $H$, was unaffected by the dietary protein:energy ratio, and in both dietary groups remained relatively unaltered throughout lactation. In group $\mathrm{H}$ the higher liver FSR recorded on day 2 of lactation resulted in a significantly greater liver ASR $(\mathrm{mg} / \mathrm{d}$ ) than that measured on day 4 , and also the rate on day 2 for group L. However, associated with the significant increase in liver weight and protein content from day 4 of lactation in group $H$ (Table 3), liver ASR was also significantly higher on days 8 and 12. Consequently, during this period the liver ASR of group $\mathrm{H}$ was also higher than that of group $\mathrm{L}(P<0.001)$, which was not significantly changed during lactation. The activity of liver RNA, apart from that on day 2 in group $\mathrm{H}$, was unaffected by the dietary protein:energy ratio and remained unchanged throughout lactation in both dietary groups.

\section{DISCUSSION}

\section{Methodology}

The female rats involved in the current study were also used to investigate the effects of dietary protein restriction on the composition of rat milk during lactation (Pine et al. 1994 c). The in vivo rates of protein synthesis were estimated immediately after each female had been used to provide a milk sample. Despite the plethora of studies investigating changes in milk composition and rates of tissue protein synthesis during lactation in rodents, the authors are unaware of any studies in which these two investigations have been combined into one experiment involving the same female. The impact of the sampling procedure, including the use of exogenous oxytocin, on the subsequent estimation of protein synthesis, particularly in the mammary gland, was therefore unknown at the start of this study.

When a diet of comparable protein:energy ratio to diet $\mathrm{H}$ was offered to female rats during an earlier experiment, mammary FSR values were increased from $59-92 \%$ per d between days 1 and 13 of lactation, although the time-course of this increase was not studied (Pine et al. 1994a). This increase confirmed the elevation in FSR reported by Jansen \& Hunsaker (1986) between days 1 and 12 of lactation, and the day 13 FSR was comparable with previously reported peak rates in well-fed females of $92 \%$ per d (Jansen \& Hunsaker, 1986), 110\% per d (Sampson \& Jansen, 1984a) and 83\% per d (Sampson et al. 1986). This increased FSR would also be associated with increased mammary ASR when combined with the gain in mammary weight during lactation (Jansen \& Hunsaker, 1986).

In the current study however, despite estimated rates of mammary FSR in both dietary groups on day 2 of lactation (52-62\% per d) being similar to those previously reported during early lactation (Jansen \& Hunsaker, 1986; Pine et al. 1994a), in group $\mathbf{H}$ the expected increase in mammary protein synthesis between days 2 and 12 of lactation was absent and at one stage mammary FSR actually exhibited a substantial and significant fall. Mammary FSR in group L was also unchanged during lactation and rates of mammary ASR in both groups reflected the situation seen with FSR. These observations suggest that the estimates of mammary protein synthesis reported here were influenced by the procedure used to sample milk. Rates of protein synthesis in the liver and muscle were however comparable with those reported in earlier studies from both this (Pine et al. 1994a) and other laboratories (Sampson \& Jansen, 1984a; Jansen \& Hunsaker, 1986), and there is 
therefore no reason to think that these estimates had been compromised by the milking regime adopted.

Using the equation developed by Sampson \& Jansen (1984b) and the milk protein content $(91.1 \mathrm{mg} / \mathrm{g}$; Pine et al. $1994 \mathrm{c})$ of females offered diet $\mathrm{H}$ and slaughtered on day 8 of lactation, milk and milk protein yields over the preceding $24 \mathrm{~h}$ were calculated to be $34 \cdot 4$ and $3.13 \mathrm{~g} / \mathrm{d}$ respectively. However, this compares with a total mammary protein synthesis of $0.97 \mathrm{~g} / \mathrm{d}$ ( $2 \times$ mammary ASR, Table 2$)$. Even ignoring the proportion of endogenous protein synthesized and the possible degradation of milk protein before secretion (Hasan et al. 1980), there is a considerable difference between milk protein yield and estimated mammary production. Other workers have reported a similar but smaller disparity between calculated and estimated mammary protein output (Sampson et al. 1986), but here this difference has been exaggerated by the inaccurate rates of mammary protein synthesis.

The milking procedure adopted here was initially designed to limit, as far as possible, any effects on these measurements. The time of day at which a milk sample was obtained was not thought to be crucial since, unlike lactose and lipid synthesis (Williamson et al. 1984), milk protein synthesis does not exhibit diurnal variations (Sampson \& Jansen, 1984b), while the period of dam and litter separation was limited to prevent an effect of milk stasis (Grigor et al. 1986). The collection of milk via physical manipulation of the gland and the estimation of mammary protein synthesis were applied to different sides whilst diethyl ether has been shown not to influence rates of tissue protein synthesis (Sampson et al. 1984). Separation of the dam from her litter for $2 \mathrm{~h}$ before measurements being taken would result in accumulation of milk within the gland. This would increase the protein content of the gland by approximately $10 \%$ reducing ASR and FSR by this amount. Given these precautions, it seems most likely that the use of exogenous oxytocin was primarily responsible for the reduced estimates of mammary protein synthesis.

The mechanism by which a large dose of exogenous oxytocin might impair protein synthesis in the mammary epithelial cell is at present unknown. However, the lower protein bound $\left(S_{B}\right)$ specific activity recorded in the present study suggests that the problem is associated with a reduction in $\left[{ }^{3} \mathrm{H}\right]$ phenylalanine incorporation into protein and not with levels of the label in the tissue free pool.

Although the flooding-dose technique has been used successfully in this and other laboratories for studying mammary protein synthesis, the results of the current study cannot be used as an accurate representation of changes in mammary protein synthesis during lactation, although the observations in other tissues do not seem to have been compromised.

\section{Lactational performance and hepatic protein synthesis}

Dams offered the high-protein-high-energy diet during lactation increased their feed intake throughout, and by day 12 this intake was approximately $43 \mathrm{~g} \mathrm{DM} / \mathrm{d}$. This elevated nutrient supply, in addition to supporting increasing litter growth throughout lactation (Fig. 3), was associated with considerable hypertrophy of the mammary gland and liver. However, such an increase in feed intake during lactation was limited by the lower protein : energy ratio of diet $\mathrm{L}$ (Fig. 1) and, as well as impairing lactational performance, would also account for the lack of such organ hypertrophy (Tables 2 and 3). In fact, the dietary protein restriction promoted considerable tissue regression during lactation and supports the findings of earlier studies involving lactating rats (Sampson \& Jansen, 1984a; Pine et $a l .1994 \mathrm{~b}$ ). The mammary gland regression is possibly associated with both a decline in mammary mass (Turner, 1973) and cellularity.

The results of the current study support the suggestion that in lactating rodents liver protein synthesis (\% per $\mathrm{d}$ ) is not influenced by dietary protein quantity/quality or stage 
of lactation (Sampson \& Jansen, $1984 a$; Jansen \& Hunsaker, 1986; Sampson et al. 1986; Millican et al. 1987; Pine et al. 1994a). Liver FSR values reported here (79-85\% per d) compare well with those of previous studies using the flooding-dose technique in rats (70-80\% per d, Sampson \& Jansen, 1984a; 85-103\% per d, Pine et al. 1994a) and mice (73-78\% per d, Millican et al. 1987). Although liver FSR appeared to be unaffected by nutrition or stage of lactation, in group $\mathrm{H}$, liver ASR $(\mathrm{mg} / \mathrm{d})$ was significantly increased from day $4(1.76 \mathrm{mg} / \mathrm{d})$ to day 12 of lactation $(2.54 \mathrm{mg} / \mathrm{d})$ as a result of considerable organ hypertrophy, while in comparison the feeding of diet $\mathrm{L}$ promoted a significant reduction in liver size and thus ASR. These observations support the conclusion that alterations in hepatic protein synthesis during lactation are determined by nutritional influences on liver size and protein content (Sampson \& Jansen, 1984a; Jansen \& Hunsaker, 1986).

\section{Muscle protein metabolism}

Previous studies involving lactating rodents have suggested that well-nourished dams, regardless of age or maturity, can satisfy their increased requirement for protein through a considerable elevation of feed intake and do not depend upon muscle protein as an endogenous nutrient source (Naismith et al. 1982; Glore \& Layman, 1985; Millican et al. 1987; Pine et al. 1994a, b). The results of the current study support this principle and also reject the possibility that in well-nourished dams muscle protein undergoes periods of depletion and repletion during lactation (Pine et al. 1994a, b). However, when such females are subjected to severe undernutrition or offered unbalanced diets (low-protein-highenergy) that suppress food intake, significant loss of carcass protein is observed. Although the use of maternal protein can have a significant impact on lactational performance (Pine et al. 1994b), this influence is constrained by the metabolic limit of such reserves (Allison $\&$ Wannemacher, 1965) and the effect of prior nutrition upon their degree of repletion (Pine et al. 1994b).

In the current study the significant loss of muscle protein from group $\mathrm{L}$ during lactation (133 $\mathrm{mg})$, although supporting the above observations, appeared to occur rapidly during early lactation and the bulk of this loss was achieved by day 8 , with little change occurring during the last $4 \mathrm{~d}$ (Fig. 4). These changes in muscle protein content reflect the previously reported pattern of carcass protein loss from similarly treated females (Pine et al. 1992). Although the results from an earlier study suggested that both an increase in degradation and a decline in synthesis were involved in the loss of muscle protein during lactation (Pine et al. $1994 \mathrm{~b}$ ), the degradation rate was calculated assuming a constant rate of protein loss throughout lactation. This assumption has now been shown to be inaccurate and the rapid loss of muscle protein during early lactation would require a much higher rate of degradation (FDR).

The suggestion that the loss of muscle protein during early lactation is associated with a dramatic increase in FDR is further supported by the fact that although in the current study severe protein restriction from parturition resulted in a significant decline in muscle FSR (3.29-2.03\% per d), this fall was not rapid and the greatest reduction occurred between days 8 and 12 of lactation ( $P=0.08$; Table 1 ). Using the average muscle FSR and protein contents (Fig. 4) of group $L$ between each slaughter point the average muscle degradation rates were calculated and are shown in Fig. 5. Between days 2 and 4 of lactation the average FDR of $13.0 \%$ per $d$ was considerably greater than the FSR $(3.1 \%$ per d) and promoted the loss of muscle protein at $34.9 \mathrm{mg} / \mathrm{d}$. As lactation proceeded, both muscle FSR and FDR fell to rates which between days 8 and 12 of lactation were not substantially different. This decline in muscle FDR during the later stages of lactation is possibly part of the mechanism that prevents excessive catabolism of maternal protein during this period and by day 12 of lactation the decline in FDR could have resulted in the 


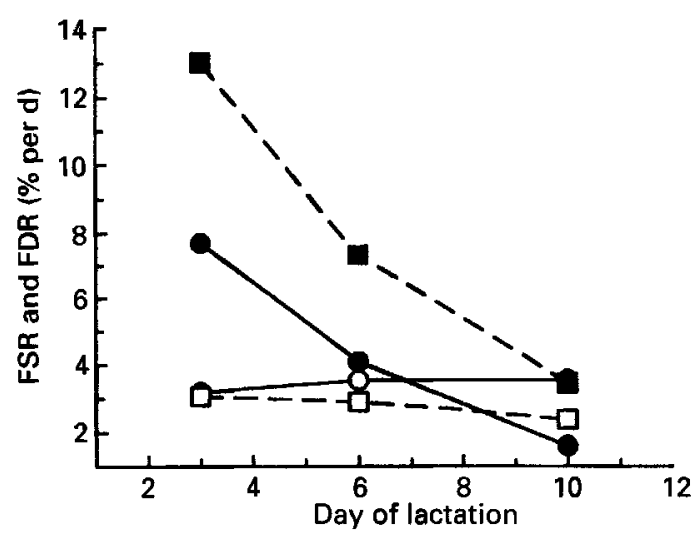

Fig. 5. Calculated rates of protein synthesis (FSR) and degradation (FDR) in the skeletal muscle (gastrocnemius) of female rats offered either a high (H)- or a low (L)-protein diet during lactation. (O), FSR, H; ( $\square$ ), FSR, L; (O), FDR, H; (ם), FDR, L. FDR were calculated using changes in the mean FSR and muscle protein content. For details of diets, see Pine et al. (1994c).

rate being lower than that of muscle FSR, and which would therefore allow the recovery of maternal protein mass. A similar mechanism has also been shown to be involved in the prevention of muscle protein loss during the early stages of starvation and protein restriction in growing animals (Millward \& Waterlow, 1978). A dramatic increase in muscle FDR is central to the rapid mobilization of maternal protein during early lactation, while the decline in protein synthesis has a smaller and later role.

The results of the current study, although in agreement with those reported by Vincent \& Lindsay (1985) and the suggestion (Bryant \& Smith, 1982) that in ewes the activity of muscle proteolytic enzymes and thus protein degradation may be increased during lactation, contrast with the conclusions of Swick \& Benevenga (1977) and observations of Champredon et al. (1990) and Baracos et al. (1991) that protein mobilization during early lactation in goats is associated primarily with a decline in muscle protein synthesis. These latter studies only estimated rates of tissue protein synthesis at one point during lactation and were compared with those of non-lactating controls, while the use of one infusion period also prevented the degradation rate from being calculated. Furthermore, since the change in muscle FSR during lactation was small and insignificant and the lactating females were in negative $\mathrm{N}$ balance $(-4.4 \mathrm{~g} / \mathrm{d}$; Baracos et al. 1991), the use of additional slaughter points could have established whether alterations in muscle proteolysis also had a key role.

It might have been expected that this loss of muscle protein from mature females would be associated with an increase in degradation since the rate of muscle protein turnover (synthesis and degradation) in such females is extremely slow (Table 1) and substantial reductions in synthesis alone could not have promoted such a rapid rate of loss (Millward et al. 1976).

In summary it can be concluded that when lactating rats are subjected to a period of severe dietary protein restriction, the rapid mobilization of their endogenous protein reserves is associated with a dramatic increase in the rate of muscle protein degradation, with the decline in protein synthesis being slower and of less importance. Excessive protein catabolism during the latter stages of lactation is however prevented by a considerable fall in FDR, possibly below that of synthesis. The estimation of in vivo mammary protein synthesis by the flooding-dose technique appears to be impaired in rats that have been previously milked using exogenous oxytocin, although rates of muscle and liver FSR were 
unaffected. Further work into the influence of exogenous oxytocin on mammary protein synthesis and how this changes with variations in dose level is required before future combined studies of milk composition and mammary protein synthesis can be attempted.

\section{APP gratefully acknowledges receipt of an Agricultural and Food Research Council} studentship. Statistical advice of Dr G. W. Horgan, Scottish Agricultural Statistics Service, is also acknowledged.

\section{REFERENCES}

Allison, J. B. \& Wannemacher, R. W. (1965). The concept and significance of labile and overall protein reserves of the body. American Journal of Clinical Nutrition 16, 445-452.

Ashford, A. J, \& Pain, V. M. (1986). Effect of diabetes on the rates of synthesis and degradation of ribosomes in rat muscle and liver in vivo. Journal of Biological Chemistry 261, 4059-4065.

Baracos, V. E., Brun-Bellut, J. \& Marie, M. (1991). Tissue protein synthesis in lactating and dry goats. British Journal of Nutrition 66, 451-465.

Belyea, R. L., Frost, G. R., Martz, F. A., Clark, J. L. \& Forkner, L. G. (1978). Body composition of dairy cattle by potassium-40 liquid scintillation detection. Journal of Dairy Science 61, 206-211.

Bryant, D. T. W. \& Smith, R. W. (1982). The effect of lactation on protein synthesis in ovine skeletal muscle. Journal of Agricultural Science (Cambridge) 99, 319-322.

Champredon, C., Debras, E., Mirand, P. P. \& Arnal, M. (1990). Methionine flux and tissue protein synthesis in lactating and dry goats. Journal of Nutrition 120, 1006-1015.

Garlick, P. J., McNurlan, M. A. \& Preedy, V. R. (1980). A rapid and convenient technique for measuring the rate of protein synthesis in tissues by the injection of $\left[{ }^{3} \mathrm{H}\right]$ phenylalanine. Biochemical Journal 192, 719-723.

Glore, S. R. \& Layman, D. K. (1985). Loss of tissues in female rats subjected to food restriction during lactation or both during gestation and lactation. Journal of Nutrition 115, 233-242.

Grigor, M. R., Poczwa, Z.\& Arthur, P. C. (1986). Milk lipid synthesis and secretion during milk stasis in the rat. Journal of Nutrition 116, 1789-1797.

Hasan, H. R., White, D. A. \& Mayer, R. J. (1980). Extensive destruction of newly synthesised casein in mammary explants in organ culture. Biochemical Journal 202, 133-138.

Jansen, G. R. \& Hunsaker, H. (1986). Effect of dietary protein and energy on protein synthesis during lactation in rats. Journal of Nutrition 116, 957-968.

Lobley, G. E. (1993). Protein metabolism and turnover. In Quantitative Aspects of Ruminant Digestion and Metabolism, pp. 313-340 [J. M. Forbes and J. France, editors]. Wallingford: C.A.B. International.

Lowry, O. H., Rosebrough, N. J., Farr, A. L. \& Randall, R. J. (1951). Protein measurement with the Folin phenol reagent. Journal of Biological Chemistry 193, 265-275.

Millican, P. E., Vernon, R. G. \& Pain, V. M. (1987). Protein metabolism in the mouse during pregnancy and lactation. Biochemical Journal 248, 251-257.

Millward, D. J., Garlick, P. J., Nnanyelugo, D. O. \& Waterlow, J. C. (1976). The relative importance of muscle protein synthesis and breakdown in the regulation of muscle mass. Biochemical Journal 156, 185-188.

Millward, D. J. \& Waterlow, J. C. (1978). Effect of nutrition on protein turnover in skeletal muscle. Federation Proceedings 37, 2283-2290.

Munro, H. N. \& Fleck, A. (1969). Analysis of tissues and body fluids for nitrogenous constituents. In Mammalian Protein Metabolism, vol. 3, pp. 425-465 [H. N. Munro, editor]. New York: Academic Press.

Naismith, D: J., Richardson, D. P. \& Pritchard, A. E. (1982). The utilization of protein and energy during lactation in the rat, with particular regard to the use of fat accumulated during pregnancy. British Journal of Nutrition 48, 433-441.

Pine, A. P., Jessop, N. S., Allan, G. F. \& Oldham, J. D. (1994a). Maternal protein reserves and their influence on lactation performance in rats. 2. Effects of dietary protein restriction during gestation and lactation on tissue protein metabolism and $\mathrm{Na}^{+}, \mathrm{K}^{+}$-ATPase (EC 3.6.1.3) activity. British Journal of Nutrition 72, 181-197.

Pine, A. P., Jessop, N. S. \& Oldham, J. D. (1992). Effect of protein realimentation on lactational performance in rats. Animal Production 54, 478A.

Pine, A. P., Jessop, N. S. \& Oldham, J. D. (1994b). Maternal protein reserves and their influence on lactational performance in rats. British Journal of Nutrition 71, 13-27.

Pine, A. P., Jessop, N. S. \& Oldham, J. D. (1994c). Maternal protein reserves and their influence on lactational performance in rats. 3 . The effects of dietary protein restriction and stage of lactation on milk composition. British Journal of Nutrition 72, 815-830.

Sainz, R. D., Calvert, C. C. \& Baldwin, R. L. (1984). 3-Methylhistidine excretion by lactating and non-lactating rats. Journal of Animal Science 59, suppl., 505.

Sainz, R. D., Calvert, C. C. \& Baldwin, R. L. (1986). Relationships among dietary protein, feed intake and tissue protein turnover in lactating rats. Journal of Nutrition 116, 1820-1829.

Sampson, D. A., Hunsaker, H. A. \& Jansen, G. R. (1986). Dietary protein quality, protein quantity and food 
intake: effects on lactation and on protein synthesis and tissue composition in mammary tissue and liver in rats. Journal of Nutrition 116, 365-375.

Sampson, D. A. \& Jansen, G. R. (1984a). Protein synthesis during lactation: no circadian variation in mammary gland and liver of rats fed diets varying in protein quality and level of intake. Journal of Nutrition 114, 1470-1478.

Sampson, D. A. \& Jansen, G. R. (1984b). Measurement of milk yield in lactating rats from pup weight gain and pup weight. Journal of Pediatric Gastroenterology and Nutrition 3, 613-617.

Sampson, D. A. \& Jansen, G. R. (1985). The effect of dietary protein quality and feeding level on milk secretion and mammary protein synthesis in the rat. Joumal of Pediatric Gastroenterology and Nutrition 4, $274-283$.

Sampson, D. A., Masor, M. \& Jansen, G. R. (1984). Protein synthesis in rat tissues during lactation. No effect of diethyl ether anaesthesia. Biochemical Journal 224, 681-683.

Swick, R. W. \& Benevenga, N. J. (1977). Labile protein reserves and protein turnover. Journal of Dairy Science $60,505-515$.

Turner, M. R. (1973). Perinatal mortality, growth and survival to weaning in offspring of rats reared on diets moderately deficient in protein. British Journal of Nutrition 29, 139-147.

Vernon, R. G. (1988). The partition of nutrients during the lactation cycle. In Nutrition and Lactation in the Dairy Cow, pp. 32-51 [P. C. Garnsworthy, editor]. London: Butterworths.

Vincent, R. \& Lindsay, D. B. (1985). Effect of pregnancy and lactation on muscle protein metabolism in sheep. Proceedings of the Nutrition Society 44, 77A.

Williamson, D. H. (1980). Integration of metabolism in tissues in the lactating rat. FEBS Letters 117, suppl. 1, K93-K105.

Williamson, D. H., Munday, M. R. \& Jones, R. G. (1984). Biochemical basis of dietary influences on the synthesis of the macronutrients of rat milk. Federation Proceedings 43, 2443-2447. 